International Research Journal of Engineering, IT \& Scientific Research (IRJEIS) Journal Homepage: http://ijcu.us/online/journal/index.php/irjeis

Vol. 2 Issue 7, July 2016, pp. 58 62

ISSN: 2454-2261 Impact Factor: 3.605

DOI: 10.6084/m9.figshare.3437309 | ORCID: 0000-0003-4919-1090 | Thomson Reuters ID: C-6767-2016 |

\title{
A Reflection on the Medium of Cinema, Film versus Digital: Which side are you on?
}

Amar Singh *

Article history:

Received May $25^{\text {th }}, 2016$

Revised June $1^{\text {st }}, 2016$

Approved June $20^{\text {th }}, 2016$

\section{Keywords:}

Cinema;

Film;

Digital;

Steven Spielberg;

Martin Scorsese;

James Cameron;

Christopher Nolan;

Keanu Reeves.

\begin{abstract}
Storytelling has been an essential part of the survival of humans and human civilization in general. Over the years humans have designed and found newer ways to narrate and preserve their memories. However, it was not until Lumière brothers found the magic of narrating stories by moving the frozen images, not until cinema was invented, the art of storytelling remained somewhere hollow. This is one such medium that encompasses all the art forms, whether painting, dance, drama, etc., or any science, whether it be physics, chemistry, math; and at times, it even succeeds revolutionizing these and other such streams. Nonetheless, since last few years, cinema is also going through certain revolution. This revolution is about the freedom of choosing the medium via which directors want to narrate their stories, that is, with film or digital. Now, this paper is an attempt to explore the possibilities that these mediums provide to cinema along with their limitations. Also, it seeks for an answer as what kind of affect and effect it produces on first, the director, and second, on the audience, when one medium is chosen over the other. This paper goes through the versions of different directors and technicians, such as Steven Spielberg, Martin Scorsese, James Cameron, Christopher Nolan, Keanu Reeves, and more, who have mastered their art form of storytelling by choosing one or both mediums of cinema and attempts to bring out the answer to the questions: Whether film should be left to die? Which one is the superlative medium, film or digital? Is digital revolutionizing cinema for real?
\end{abstract}

Copyright @ 2016 International Journal of College and University. All rights reserved.

Article cited by | DOI |Orcid | OAI DOAJ | Thomson Reuters | Scopus |

Author correspondence:

First Author,

Amar Singh, Assistant Professor, Department of English, Mahila Mahavidyalaya, Banaras Hindu University Email: amarsnghbhu@gmail.com

\section{Introduction}

Film is dying, panting its last breath. In the last few years, Digital has changed the scenario for the moviemakers breaking an aperture of wider opportunities of experiments in cinema. We as an audience (and filmmakers) are now provided with a choice as to what medium do we want to go for in cinema to realize our experiences: film or digital or does it even matter? The context of medium seeks our attention here because it is directly associated with the aesthetics of cinema, as choosing one over the other or going for both will certainly alter the way we experience cinema. See, changes are bound to happen, this is the universal law, but it is happening for the good or bad, that seeks contemplation.

The debate over film and digital has been going on since last few years, but it gained impetus altogether when in 2014 directors like Christopher Nolan, J J Abrams, Quentin Tarantino and Judd Apatow came to the fore to save the films and ensuring that they could still be shot and screened on the same. Those who follow Hollywood movies closely and the news around it, they know the love affair of directors like Steven Spielberg, Martin Scorsese, Christopher Nolan and Quentin Tarantino with films. Whereas Spielberg has

\footnotetext{
* Amar Singh, Assistant Professor, Department of English, Mahila Mahavidyalaya, Banaras Hindu University
} 
bought a dozen of Moviolas with its spare parts and has even recruited technicians who can take care of it so that he can edit his movies on film (Murch, 79), Tarantino on the other hand has unabashedly declared that he will never ever make movies on digital. The other side are the directors like Nolan and Scorsese, who though want films to survive and believe we are not at a stage where the film should be replaced completely with digital, but they are open to ideas - we can see that Martin Scorsese has made Hugo on ALEXA which he wanted to experiment as to what he can do and achieve on digital; for him it was one other medium for narrating his story that could have been only accomplished better with shooting digitally rather than on film.

\section{Research Method}

This paper tackles the issue of the medium, film or digital, as which of them provides its services at best technically and aesthetically to cinema. Since, the inchoation of cinema, the film has served as an ideal medium, and did develop itself with the passage of time. However, with the recent developments in last few years in photography, digital has replaced the medium of film for several reasons that includes low-cost handling and easy access to even amateurs. The result of this outburst of digital medium has been the replacement of film altogether; hence, the medium is almost near to its end. This paper, therefore, brings up the issue, which medium is best for cinematic narration? In seeking the answer, this paper goes through the interviews of major directors and technicians, sampled through newspapers, documentaries, books, articles, and so on, who have worked on either of the mediums or both. Directors like Steven Spielberg, Martin Scorsese, Christopher Nolan, Keanu Reeves, and others shed light on as why film needs saving when a wider range of possibility is open with digital, which is not feasible with film. By going through their versions, a possible outcome is reached that film is more attached with the aesthetic sensibility of the moviemakers as well as with the audience. It definitely needs saving for several reasons including its archivability. In the end, however, as this paper analyses, it becomes more of an option for the filmmakers as in which medium they find themselves more expressive.

\section{Results and Analysis \\ Film versus Digital}

The cutters were the first to switch on to digital but it was necessitated by the ever-increasing use of frantic montage techniques popularized by filmmakers like Martin Scorsese in films like Goodfellas (1990). However, the Computer Generated Image (CGI) were used in movies like Jurrasic Park (1993) and Forrest Gump (1994) and their use was widely applauded in them, but it was the magnum opus animated movie Toy Story (1995) which was completely made on computers and was a massive hit. It provided the much-needed guts to filmmakers who were willing to experiment and hence, we received movies like Titanic (1997) and Gladiator (2000), and their success continued with Lord of the Rings trilogy (2001-03) and Harry Potter series (2001-11). All these movies crashed the box-office with their huge success. Not only they made studios tons of money, but they also showed that digital is now ready to change the ambience of cinema. If there were any doubts then all were swept aside when Slumdog Millionaire (2008) grabbed eight Academy Awards including Best Picture in 2009. No doubts were left that cinema has ushered into a new era. Digital is cheaper, easier to handle, images are sharp, plus it helps to bring our vision alive the way we would have never imagined before. So, when digital possess such an exceptional repertoire, then why still there are hesitations and skepticisms among many directors when it comes to digital filmmaking? Is it the nostalgia that works for these filmmakers who want to connect themselves with the legacy established since the time of Lumière brothers, or does the film really bring out some magic that digital does not possess right now? Tacita Dean, a filmmaker, who loves to work on film, is saddened by the fact that it is being replaced with the digital and she wonders why they both cannot exist side by side. It is not that the budding directors are not willing to work on $16 \mathrm{~mm}$ and $35 \mathrm{~mm}$ film, but slowly market is replacing it with the digital. For her it is all about the discipline that comes from working on films that one can never acquire from working in any other medium:

Film is chemistry: chemistry that has produced the miracle of moving image.... My relationship to film begins at that moment of shooting, and ends in the moment of projection. Along the way, there are several stages of magical transformation that imbue the work with varying layers of intensity. This is why the film image is different from digital image: it is not only emulsion versus pixels, or light versus electronics but something deeper - something to do with poetry. ("Save celluloid, for art's sake")

'Something to do with poetry', the very phrase encompasses the emotions that resonate the feelings of all who feel an unbreakable connection with film, that though may appear as imperfect but its beauty lies within

\footnotetext{
*A quick reading can be done to understand the transformation from celluloid to digital by going through the section "Celluloid to Digital" in Eyewitness Companions: Films Eyewitness Companions: Films.
} 
the same: “(Film) has a scent and it is imperfect. If you get too close to the moving image, it's like imperfect. If you get too close to the moving image, it's like impressionist art. And if you stand back, it can be utterly photorealistic" (Steven Spielberg, "Steven Spielberg and Martin Scorsese: the joy of celluloid"). Ivan Radford in his article "Don't keep it reel: why there's life after 35mm" argues that there is a lot of romanticizing that goes with film and Tacita Dean's Film (at Tate Modern until March) perfectly captures the nostalgic element that dates as back as to Geroges Melies, but the question remains the same, is digital not better?

Keanu Reeves, whose The Matrix (1999) is among the cardinal movies that showed what we can achieve with digital, has produced a wonderful documentary Side by Side (2012) where he investigates the past and the future of filmmaking and how technological development has been a crucial element of cinema history:

I grew up with film. I understand how it can make you feel nostalgic. It stands for a halcyon past, like memories of your mother's cooking. Celluloid is a fantastic, romantic medium. But technology is evolving fast, and in exciting ways. And that's the reason I wanted to produce and present Side by Side, a documentary that asks how film-making is changing in the digital age. ("Keanu Reeves: the future of cinema")

This documentary is great because here he does not propagate analog over digital or vice versa, but he efforts here to bring the diverse views of different directors as how and what they feel about the change that is taking place.

The advocates of digital argue a valid point that it has democratized the filmmaking, which thus, has provided the viewers with an option of watching the movies of their taste. But as so it is happening, this democratization comes with its own consequences of decadence in content, a point that David Lynch voices in the documentary: "Everybody and his little brother has a piece of paper and a pencil, but how many great stories have been written on that piece of paper? Now the same thing's gonna happen in, you know, cinema." The scenario seems to be worrisome because we are on the cliffhanger still not knowing what kind of taste it will develop for the future generation, a concern exclaimed by a producer, Lorenzo di Bonaventura, that "(his kids) will not have the quality that had growing up 'cause there isn't somebody there - there isn't a tastemaker involved." Martin Scorsese concerns the same as he doubts if 'our younger generation believes anything anymore on the screen. It's not real'.

Now, it seems to be an overrated statement when issues regarding the dearth of tastemaker in digital filmmaking are raised. What about James Cameron and David Fincher? James Cameron is among the pioneers of digital filmmaking who divided the course of cinema into pre-Avatar and post-Avatar era and is still pushing the boundaries, experimenting and innovating as what more can be achieved with this new technology. Digital filmmaking has its own rules and semantics, and it is foolhardy to consider that it is anywhere near 'simple', as Cameron mentions:

You have this idea that you could home in on a mathematically perfect model for creating reality if you just throw enough computing power at it and you just throw enough software at it. Guess what we found? It didn't work. It required that I, the artist, and people who were trained in photography and looking at how light interacted with things to figure out how to write the code to make it look "real"."

If one can do that, hit the right codes, his imagination may pan out the way he would have never imagined to achieve before. It is a boon for ambitious directors like Cameron who wish to bring out their mind before the audience, which he admits he could have never thought to achieve with the film, "I wanted to whatever I would imagine to be something that we could realize. I saw the door opening on a field of possibilities that you just couldn't do with film." In addition, for the ones who complain about cinema becoming more and more "unreal," James Cameron has a question to them, "when was it ever real? There was a kind of a wall there and nothing over there. There was thirty people standing around. There was a guy with a boom mic.... Your "street night exterior New York" was a day Interior Burbank. What was ever real?"

Walter Murch, renowned film editor and the author of In The Blink of An Eye, compares the transformation from film to digital with the transformation that took place in painting from fresco to oil paint on canvas. The dexterity that is applied in fresco is akin to the observation of minute details that needed to be taken care of when it comes to working on film: "The nature of working with film has been more like painting in fresco than oil. It's so heterogeneous, with so many technologies woven together in a complex and expensive fabric, that filmmaking is almost by definition impossible for a single person to control" (Murch, 141). However, with the coming of digital things have changed and it is becoming more and more accessible to bring out the vision of director and to give an autocratic control to him. If someone does not like what he sees on the screen then he can wipe it all out and colour it again with the pigments of his imagination very much like an oil painting.

Now, in all these fascinating analogies that artists draw to glorify analog or digital, Christopher Nolan has his own theory about digital (that he mentions in the documentary Side by Side): 
What I find is, the manipulations that digital media like to do - they are seductive, but ultimately, they're a little bit hollow. The analogy I would use is, I remember the summer when Chips Ahoy, or whoever, they came out with these chocolate chip cookies that were like they just came out of the oven, and they were soft. It was like, "Oh, this is amazing. It's a soft cookie." Then after a couple of months, you're like, "Oh, no, this is some horrible chemical crap that's giving this bad illusion that fools you at first."

As per now, we have gone through a range of theories and arguments favouring either analog or digital, and no matter what people choose, the fact cannot be ignored that it is an exciting time for cinema with so much innovation going on. However, the pressing issues that need our immediate retrospect here is the archiving of digital images and 'fading out of the projectionists from cinema'. The words of Keanu Reeves on the issue of archiving echoes the sentiments of everyone who grew up on film:

Archiving digital images is a technological dilemma. The idea of that discovered shoebox of pictures, or wedding album, will not exist digitally in your camera or on your computer or in a "cloud": you should print them. I often feel a photochemical image contains the mass of the subject and dimension; a digital image often feels as if it is mass-less. This could be nostalgia or simply how I learned to see. Others will not have this learning: they will probably never experience a photochemical image. Is this loss a tragedy, a revolution, an evolution? What have we lost, and what have we gained? ("Steven Spielberg and Martin Scorsese: the joy of celluloid")

In addition, the other issue came with the rapid transformation of theatres from analog to digital that leads to the unemployment of projectionists. Though by getting digital projectors things have become easier and grown much better in quality, controlled by the push of buttons, reduction in human and technical errs, yet what we are losing is irreparable. "By ushering in digital and ushering out people, it's not the medium that's under threat, it's the wealth of knowledge the industry is set to lose, as the art of projecting gives way to pixels and software packages" (Ivan Radford, "Don't keep it reel").

\section{Conclusion}

Now, this debate is an unending loop where one can argue over and over with apt points, but the matter of fact remains the same that though the innovations that are going on will certainly affect our sense of watching movies but we are not in a position yet where we can replace film altogether. Amirose Eisenbach, the former senior editor of AMC Movie News and film critic, shoots the target with the point that the freedom should be given to the directors and it should depend upon the project that they are undertaking (just as Martin Scorsese did with Hugo). 'Watching a movie on film is like listening music on vinyl that fills your room with warmth that you don't get with your ipod' ("The Debate of Film Vs. Digital"). Evolution is the absolute truth, whether it is life or art. It does not matter how much we revere film, the fact is its days are numbered. And we should not mourn for this because whatever is happening will only help cinema to achieve the purpose with which it started its journey, that is, to show people magic, to give a new lease to the lost souls, to help them to dream again. We are in a position where cinema has literally become akin to dreams. All we need to do is to keep intact our past with the present so that we may build a shiny future, because it is with film that we started to dream and even if it seems imperfect, it has its own charm like the beauty of our mother:

The cinema began with a passionate, physical relationship between celluloid and the artists and craftsmen and technicians who handled it, manipulated it, and came to know it the way a lover comes to know every inch of the body of the beloved. No matter where the cinema goes, we cannot afford to lose sight of its beginnings. (Martin Scorsese, "Steven Spielberg and Martin Scorsese: the joy of celluloid")

\section{Acknowledgement}

I am extending my thanks and gratitude to the editors of ICJU for accepting my paper for their reputed journal. I would also like to extend my sincere and deepest thanks to Professor Anita Singh, Department of English, Banaras Hindu University, for helping me to shape the idea of this paper.

\section{References}

[1] "The Debate Of Film Vs Digital." YouTube. AMC News, 23 Oct. 2014. Web. 23 Oct. 2014. <https://www.youtube.com/watch?v=B2Wv_EaIKC0\&list=WL\&index=8>.

[2] Dean, Tacita. "Save Celluloid, for Art's Sake." The Guardian. N.p., 22 Feb. 2011. Web. 9 July 2014. <http://www.theguardian.com/artanddesign/2011/feb/22/tacita-dean-16mm-film>.

[3] Dean, Tacita. "Steven Spielberg \& Martin Scorsese: The Joy of Celluloid." The Guardian. N.p., 10 Oct. 2011. Web. 9 July 2014. <http://www.theguardian.com/artanddesign/2011/oct/10/steven-spielbergmartin-scorsese-celluloid>. 
[4] Murch, Walter. In the Blink of An Eye. $2^{\text {nd }}$ ed. Los Angeles: Sileman-James Press, 2001. Print.

[5] Radford, Ivan. "Don't Keep It Reel: Why There's Life after 35mm." The Guardian. N.p., 29 Nov. 2011. Web. 9 July 2014. <http://www.theguardian.com/film/2011/nov/29/life-after-35mm-digital-film>.

[6] Reeves, Keanu. "Keanu Reeves: The Future of Cinema Keanu Reeves." The Guardian 14 Feb. 2013. Web. <https://www.theguardian.com/film/2013/feb/14/keanu-reeves-future-of-cinema>.

[7] Side by Side. Dir. Christopher Kenneally. Perf. Christopher Nolan, James Cameron, David Fincher, David Lynch, Robert Rodriguez, Martin Scorsese, Steven Soderbergh, Keanu Reeves. Tribeca Film, 2013. DVD.

\section{Biography of Author}

\begin{tabular}{|l|l|}
\hline The author of this paper, Dr. Amar Singh, is an Assistant Professor in English, Mahila \\
Mahavidyalaya, Banaras Hindu University. He has done his Ph.D. on the cinema of Christopher \\
Nolan, "Hyperrealism and Christopher Nolan's Cinematic Texts."
\end{tabular}

